\title{
Bank Guarantees in Iranian Law
}

\author{
Somaye Moinfar ${ }^{1}$, Masoumeh Esmaeeli ${ }^{2}$, Elham Taghizadeh $^{3} \&$ Hossein Hassani $^{4}$ \\ ${ }^{1}$ Department of Private Law, Science and Research branch, Islamic Azad University, Tehran, Iran. \\ ${ }^{2}$ Shiraz University, Shiraz, Iran \\ ${ }^{3}$ Shahrekord University, Shahrekord, Iran \\ ${ }^{4}$ Department of Private Law, Shahrekord Branch, Islamic Azad University, Shahrekord, Iran \\ Correspondence: Hossein Hassani, Department of Private Law, Shahrekord Branch, Islamic Azad University, \\ Shahrekord, Iran. E-mail: phd.hhspl@gmail.com
}

Received: February 14, 2016 Accepted: March 8, 2016 Online Published: March 31, 2016

doi:10.5539/jpl.v9n2p181 URL: http://dx.doi.org/10.5539/jpl.v9n2p181

\begin{abstract}
This paper aims at investigating bank guarantees in Iranian law and exploring new and different bases for the nature of bank guarantees that create liabilities and make accepting this legal action simpler for community members. In other words, we have been in a position to answer these questions: What is the nature of bank guarantees? In other words, do bank guarantees include civil or commercial guarantees? Finally, according to the proposed principles and introduced ideas, it seems that bank guarantees cannot act as a Civil or Commercial Guarantee. It should also be acknowledged that bank guarantee letter is an innovative financial tool that is very important in commercial contracts and in particular international contracts, because they minimize economic risk of the contract and are strong executive guaranty. In general, no contract can be executed or take effect without bank guarantees and insurance.
\end{abstract}

Keywords: Bank Guarantee, Civil Guarantee (Transferring of Obligation to Obligation), Commercial Guarantee, Annexing the obligation to obligation, Joint and Several Liabilities

\section{Introduction}

The purpose of issuing some guarantees, is that whereby, in case of failure of the guaranteed party (principal debtor) to do these obligations, the issuer commits to pay a certain amount to the beneficiary (one to whom the guarantee is given) at the request of the party who provides goods or services (guaranteed party) in accordance with an agreement between the guaranteed party and the beneficiary (buyer and seller or contractor and employer), (Akhlaqi 1989, 51-61).

Similarity of bank guarantee with civil guarantee enshrined in Civil Code has led some courts to know it subordinate to civil guarantee rules, i.e., transferring of obligation to obligation. According to the principle of independence of the bank guarantee, guarantor bank's commitment is a principal and independent obligation and is not subordinate to underlying contract of the guaranteed party and beneficiary. This is the most important difference between a civil guarantee and a bank guarantee letter (Shahbazi, 2004, 125) Independence of the bank guarantee letter means abstraction of the underlying contract led to the issuance of the guarantee.

Thus, bank cannot rely on defenses and objections arising from the underlying contract (-PEPRE.1977) Based on Trade Law articles, commercial guarantee contract leads to annexation of guarantor's obligation to guaranteed party's obligation. The guarantee enshrined in these articles is a consequential commitment. Therefore, as in civil guarantee, commercial guarantor can also resort to criticisms existing at underlying contract between the guaranteed party and beneficiary. However, bank guarantee cannot fit within the commercial guarantee (Article 408 of the Skin Trade Act, 2004, 115). Accordingly, the bank guarantee letter cannot act as civil or commercial guarantee.

\section{Guarantee}

According to Article 684 of the Civil Code, contract of guarantee is to take the responsibility of a property which is on the other individual. In this case, the committed individual is guarantor, the other party is beneficiary and the third party is called guaranteed party or principal debtor. According to Article 685 of the Civil Code, the consent of the principal debtor is not required in guarantee. But guarantor and beneficiary's consent is required. 
If contract of guarantee is termed, beneficiary cannot demand for his/her debt before the expiration of the term (Article 702 of the Civil Code). When the contract was correctly concluded, the guaranteed party's obligation is reimbursed and guarantor shall be subordinate to all of the Guaranteed Party's obligations under the Trust (Article 698 of Civil Code). If guarantee has taken place with the principal debtor's request (guaranteed party), the guarantor can refer to guaranteed party after paying debt. If guarantor has gratuitously guaranteed without any permission, $\mathrm{s} /$ he does not have the right of referring to the guaranteed party (Articles $709 \& 720$ of the Civil Code). In contract of guarantee, it can be agreed on discard of guarantee if beneficiary does not demand for bailment (Money Guarantee) up to Maturity of guarantee letter.

\section{Bank Guarantee}

Bank guarantee is a normal or official writing including a contractual guarantee or commitment in any form like a guarantee letter whereby an individual guarantees something on parole to be released from prison. A personal guarantee is a promise (Letter of Guarantee) made by a specific person and if a bank is the guarantor, it is called bank guarantee (Jafari-Langroudi, 1998, 2421). In other words, bank guarantee is a personal guarantee (guarantor) towards bank to accept responsibility for some other party's debt (the debtor) in the event the debtor fails to pay it (Thomson, 1957, 244) However, the bank guarantee has been defined as a contract or document whereby the issuer (guarantor) commits against beneficiary at the request of the applicant (the guaranteed party) to pay a certain amount of cash about a specific issue related to the guaranteed party, to beneficiary or to the order of him/her without any conditions, on-demand or at certain maturity (Akhlaqi, 1989, 156).

\section{The Concept of Bank Guarantee}

Lawyers have offered different definitions of this fledgling legal document for example it has been said that: a normal or formal writing including contractual guarantee or commitment in any form such as a bank guarantee letter in which an individual guarantees something on parole to be released. A personal guarantee is a promise (guarantee) made by a specific person and if a bank is the guarantor, it is called bank guarantee 1 (Jafari-Langroudi, 1998, 2421) In other words, bank guarantee is a subordinate and consequential commitment whereby bank accepts responsibility for some other party's debt (the debtor) in the event the debtor fails to pay it.

However, the bank guarantee letter has been defined as a contract or document whereby the issuer (guarantor) commits against beneficiary at the request of the applicant (the guaranteed party) to pay a certain amount of cash about a specific issue related to the guaranteed party, to beneficiary or to the order of him/her without any conditions, on-demand or at certain maturity (Akhlaqi, 1989, 156).

\section{The Nature of Bank Guarantee}

Bank guarantee are one of the types of Commercial Documentary Credits. Letter of Credit, by definition, is a document or contract whereby a bank (Opening Bank) at the request and in accordance with customer's orders (The applicant for the credit) pays an amount in cash to a third party (beneficiary) or pay or accept business documents (bills) issued by beneficiary. In a manner that can be seen, letters of credit are set according to customer's demand or orderer, and have typically three sides:

1. "Issuer" means a bank or credit union that issues the letter of credit;

2. «Client» or orderer, namely the person who has requested the issuer for the issuance or the opening of credit.

3. Beneficiary has the right to claim the credit according to credit conditions (Mohebbi, 2005: 242).

\section{The Purpose of Bank Guarantee}

Bank Guarantee is an important tool in commercial contracts particularly international contracts, because it minimizes economic risk of the contract and is considered a powerful enforcement. International contracts without having a valid support such as bank guarantee letters lack a reliable legal support. In these circumstances, bank guarantee is an innovative financial instrument, as if a party did not fulfill his/her obligation the other party can receive guarantee amount and its profit in cash and escape from legal dispute procedures and the delay in reaching the right (Mohebbi, 2005: 243). The purpose of issuing guarantee is different depending on the type of the underlying contract and can be a guarantee for good performance, refunding prepayment and other issues that will be discussed in the following (Here mentioning two things are necessary). Firstly, the guarantee does not legally replace the guaranteed party's obligations and consequently, issuing guarantee does not pass or run his/her commitment to bank, but in case of negligence and violation by the guaranteed party, paying damage caused by the breach of the obligation about the amount of guarantee is bank's obligation. Secondly, with the issue of a bank guarantee the guaranteed party is not exempted to do his/her contractual/non-contractual obligations about compensation (Mohebbi, 2005: 242). 


\subsection{Good Performance Guarantee}

Some guarantees are issued whereby the issuer commits to pay a certain amount to the beneficiary in case of the guaranteed party's failure from these obligations in accordance with contract terms between the guaranteed party and beneficiary (buyer and seller), or contractor and client whom offered goods or services (the guaranteed party) at the request of the party (Akhlaqi, 1989, 51-61).

\subsection{Guarantee for Retention Advance Payment}

The purpose of issuance of some bank guarantee letter is to refund advance payment. These guarantee letters are commitments by banks to pay a certain amount of cash to employer or beneficiary in case of contractor or guaranteed party's failure (Kashani 1996,148).

\subsection{Tender Guarantee}

Sometimes the purpose of issuing a letter of guarantee is to participate to tender or auction. This bank guarantee letter is a document whereby the issuer as guarantor agrees to pay a certain amount to the order of beneficiary (buyer or employer) that has invited to tender or auction at the request of the applicant (the guaranteed party), vendor or contractor (Akhlaqi, 1989:157, Kashani, 1996:14).

\subsection{Retention Money Guarantee (Money Guarantee)}

Usually, in manufacturing or project contracts, some money is paid as intermediate payments. Such payments are done when the project engineer confirms that part of the project has been completed or installation phase tests are confirmed. Intermediate payments enable the contractor to have required liquidity to pay living expenses at the duration of carrying out the project.

\section{Types Letter of Guarantees}

Many letter of guarantees are issued by banks, financial companies and insurance companies, including counter guarantees and superior guarantees.

\subsection{Counter Guarantee}

Sometimes in an international contract, the seller requests for a good performance guarantee from the buyer. The buyer or contractor provides such a letter of guarantee from a bank in his/her country, but the bank issues the guarantee in favor of a local bank in the country where the seller or the employer lives and directly guarantees in favor of the seller or the employer. Then the local bank issues a counter guarantee and submits it to the seller (Asimov, 1999: 87) An important difference between normal and counter guarantees is that issuing normal guarantees is subject to the Deposit of Collaterals from the guaranteed party. But in counter guarantee, another bank takes the place of collateral as the beneficiary for the bank that has issued the original letter of guarantee (Massoudi, 2012: 155)

\subsection{Superior Guarantee}

Superior or excellent guarantee is a special type of indirect letter of guarantee and is actually a guarantee of the guarantee. This guarantee is demanded by the beneficiary that wants to receive the letter of guarantee of a more valid bank in addition to letter of guarantee of a debtor bank that may not be famous. Demanding for superior guarantee is done by a guarantor bank that undertakes to repay amounts that the superior guarantor is obliged to pay it through obligations arising from superior guarantees (Asimov, 1999: 687-688).

\subsection{The Parties of Bank Guarantees}

A bank guarantee is dependent on three factors:

1 - The guaranteed party or applicant

2- Guarantor or guarantor bank

\section{3- Beneficiary}

\section{The Contract of Guarantee as the Issue of Civil Code}

Similarity of bank guarantee letter with civil guarantee enshrined in Civil Code has led some courts to know it subordinate to civil guarantee rules, i.e., transferring of obligation to obligation. For example, in grain transport contracts, the contractor receives the necessary amount of bags from the corresponding Grain Office and is committed to the delivery of bags after distribution of wheat and barley. In the case of the missing bags, s/he must pay the price and someone must guarantee for the contractor. The authors of Civil Code have embraced a concept of guarantee and transferring the obligation of debtor to that of the guarantor (Katouzian, 2010, Vol. 4: 228; Kashani, 2009: 278) But the bank guarantee is a principal and essentially independent obligation initially 
created for the bank, not that to be transmitted to the bank by the original committer. Secondly, the civil guarantee is a subordinate contract. A commitment that guarantor intends to guarantee it, is the reason for guarantor's commitment and the fate of the guarantor's commitment is dependent on the commitment of the main debtor. According to the principle of independence of a bank guarantees, the commitment of the guarantor bank is a principal and essentially independent obligation and is not subject to the underlying contract of the guaranteed party and beneficiary. This is the most important difference between the civil guarantee and bank guarantee letter. (Shahbazi, 2006: 125). In other words, although the purpose of a letter of guarantee is to guarantee the obligee or beneficiary against damages caused by the obliged subject's offense or the guaranteed party in the underlying contract but the beneficiary's right to claim bailment, is measured only by referring to the provisions contained in the context of a specific guarantee letter and in accordance with it. Thus, the bank cannot rely on defenses and objections arising from the underlying contract (18 - 19: PEPRE.1977) The bank cannot rely on defenses, such as implementation of beneficiary's commitments or lack of eligibility for demanding funds, against beneficiary's request for bailment while it is apparently compatible with letter of guarantee contents

\subsection{Commercial Guarantees (Annexing of Obligation to Obligation)}

Under Article 249 of the Commercial Code, in the commercial documents, issuer and counter signer of document are responsible to pay document fee in a partnership manner.

On the tenth section of this law (Articles 402 to 411), entitled "Guarantee" certain provisions have been expressed. The purpose of these regulations is to introduce the term Joint in contract of guarantee, i.e., eliminating the Transferring of Obligation to Obligation from guarantee. Trade Law has recognized jointness (partnership) in private contracts. In accordance with Article 402 of Trade Law, guarantor is allowed to ask beneficiary to refer to principal debtor and then refer to him/her if failed to receive his/her demand (whether in specific contract or in guarantee letter) when this is stipulated between both parties. Trade Law has eliminated the effect or function of term Transferring of Obligation to Obligation implicated from Articles 684 and 698 (Fathi, 150-151: 1990) without changing in elements of contract of guarantee or terms of coming into being and its realization. Moreover, in accordance with Article 403 of Trade Law, "in all cases considered as joint guarantee thereby laws or private contracts, the creditor can collectively refer to the guarantor and the principal debtor or $\mathrm{s} / \mathrm{he}$ can refer to other party for all or part of a debt after referring to one of them and failure to receive demand. With enforcing partnership laws, this Article has known private contracts as the origins of creating partnership guarantee. According to aforementioned articles, commercial guarantee contract leads to annexing of guarantor's obligation to the guaranteed party's obligation. The guarantee included in these articles is a consequential commitment. Accordingly, similar to civil guarantor, commercial guarantor can also resort to objections stipulated in underlying contract between the guaranteed party and the beneficiary. However, bank guarantee cannot play role as commercial guarantee. Because as mentioned before, bank guarantee letter is a commitment independent from the underlying contract while commercial guarantee is a consequential commitment. Moreover, the objections of underlying contract mentioned in bank guarantee letter are not addressed and consequently they will not be transferred to bank. While in commercial guarantees, such as civil guarantee, the basic point is the capability of relying on objections of underlying contract. As a result, guarantor cannot act for termination of the underlying contract toward the beneficiary. On the other hand, cutting the relationship between a bank guarantee letter and the underlying contract prevents the beneficiary to ask bank to pay bailment with resorting to the underlying contract. In commercial guarantee, the guarantor is entitled to refer to all the objections that the guaranteed party can raise against the holder of the document as his/her deputy. Consequently, the bank guarantee cannot be a civil or commercial guarantee.

\subsection{Joint Guarantee or Annexing of Obligation to Obligation}

In general people close contracts with civil figures to use the facilities and meet their needs and due to this are sometimes obliged and sometimes obligee. But in the meantime, there is always concern for the obligee for the conditions must be foreseen in the contract to receive demands from the principal debtor and others easily if s/he failed to do obligations or was not able to pay the debt. However, the contract of guarantee is a perfect instrument for such commitments and guarantees through which the obligee can choose a useful strategy to achieve goals. However, to achieve this, Civil Code (Contractual Guarantee) has just predicted the guarantee for Transferring of Obligation to Obligation and this is not sufficient; although, it has not prohibited the joint guarantee. Consequently, we should inevitably use regulations and other legal institutions including Guarantee section set forth in the Commercial Code and Article 10 of Civil Code and benefit from joint guarantee together with transferring guarantee. Accordingly, since the creation of the joint and several liabilities is an important issue considered by legislator for observing the rights of people, eliminating some of the problems of the people 
and ensuring commitment and compensation and is a tool that can create great security with brief formalities in legal and financial relations of the parties in particular the obligee, it is suitable to propose a procedure to create joint guarantee in civil rights that has been less considered. However, although the theory of transferring the obligation to obligation is adequately justified, but this kind of guarantee has not prohibited joint guarantee and people can apply guarantee for Annexing of Obligation to Obligation together with guarantee for Transferring of Obligation to Obligation.

However, the main reason for undermine of Joint and Several Liabilities originates from the history and background of our legal system has not accepted numerous debtors for a debt for various reasons and according to common belief in jurisprudential that has also affected the Civil Code, Transfer of obligation to Obligation occurs due to contract of guarantee (and not Addition of Obligation to Obligation). However, in the current law of the country, we believe that by Articles 402 and 403 of the Commercial Code and Article 10 of the Civil Code, the possibility of joint and several liabilities will not be difficult. Since, creating joint and several liabilities is an important tool considered by legislators in legal systems to do commitments and compensate costs and damages, it is an instrument that creates great security in legal and financial relations of both parties in particular for the debtor and oblige. Accordingly, it is important to know whether religious and civil law perspective have prohibited us to apply this instrument or not. Does verbal reiterating on possibility of joint guarantee through Article 10 resolve the challenges ahead of this issue? Is Shiite jurists' opinion about Transferring of Obligation to Obligation entered to Civil Code one of JUS COGENS? How can we create joint guarantee if Articles 402-404 of Commercial Law are the basis for creating it?

\section{Conclusion}

Considering the aforementioned points, it is concluded that the bank guarantee is a document or commercial tool for Trade Law rather than to be Civil Rights Contract and in particular contract of guarantee. However, considering a variety of letter of guarantees, there are many similarities between contracts of guarantee for civil rights with this commercial document and this cannot be denied. If we want to investigate this commercial document/bank guarantee letter in the form of civil rights, some of the conditions of the contract of guarantee in Civil Code apply for this commercial document. However, it is more similar to private contracts of Article 10 of the Civil Code and general rules of contracts are not dominated on it. As discussed in different opinions about the legal nature of the bank guarantee, letter of guarantee is like a tree rooted in contract of guarantee with foliage beyond the contract of guarantee grown in jurisprudence and Civil Code. That is because Domestic and international economic interactions are growing day to day and facilitation of the exchange of goods and services is essential for economic development. It is required that commercial documents to be used by this broad and diverse economy with a new form and great performance. For example it is mentioned in jurisprudence that it is invalid to guarantee unproven properties. Following Islamic jurisprudence, Civil Law has verified this in Article 691. However, we know that Good performance guarantee is one of the most common types of guarantee letters with wild applications through which bank guarantees something whereby it is not clear yet whether contractor will implement commitments in the best form or not.

Therefore, before establishing grounds for guarantee or debt, bank will guarantee the issue and this is the aforementioned foliage has gone beyond the roots and daily requirements of community and the new economy needs such guarantees and economic/commercial tools. Unlike contract of guarantee leading to "Transferring of Obligation to Obligation", bank guarantee does not release the guaranteed party from the commitment or principal debt and beneficiary of guarantee letter can demand the guaranteed party to do commitments (the oblige of the base and principal contract) or demand bank for the bailment. Accordingly, liabilities are jointly in bank guarantee $\mathrm{r}$ and the beneficiary has authority for return. Contract of guarantee in Civil Code is one of the contract of tolerances while its amount and duration in bank guarantee is one of and the main and important elements. According to what mentioned before, some of bank guarantee letters are included as contractual guarantee such as "Advance Payment Guarantee" and some are not included within contractual guarantee like Good Performance Guarantee. In general, bank guarantee letters are a type of letter of credit but have also many similarities with contract of guarantee too as follows:

Bank guarantee is a consequential guarantee as a contractual guarantee and in the event of nullity, cancellation or termination of the underlying contract, it is invalid too. Because if the underlying contract is terminated, revoked or dissolved, the beneficiary can demand for them and in other words the grounds for guarantee are removed. Bank guarantee are not contractual guarantee and are included as contractual guarantee and not only they are not conflicting with the current laws of the country, public order and ethical norms, but also create a kind of commercial order and thus can be classified as commercial contracts and binding documents. Bank guarantee is an innovative financial tool has been manifested of high importance in commercial in particular international 
contracts because it minimizes economic risk and is a strong enforcement and, in general, no contract has executive function without having bank guarantee and insurance.

\section{References}

Akhlaqi, B. (1989). discussion of the bank guarantee. Bar Association Journal. Tehran: Central Bar Association, Issues 148-149.

Ashminov, K. (2000). international trade law. Translated by Behrouz Akhlaqi, Tehran: Organization of Study and Compilation of Humanities Books (SAMT).

Civil Code.

Commercial Law.

Fathi, A. (2000). Defense Technique (Legal Affairs). Tehran: Ashkan

Ghamami, M. (1997). the civil liability of the state toward employees' acts. Tehran: Dadgostar Publication, Ja'fari Langroodi, M. (1999). rights and obligations, Ganj-e Danesh publications, Third Edition.

Kashani, M. (1997). Thoughts in Today's Laws. Tehran: Hoquqdan Publications, Vol. 2.

Katoozian, N. (2008). The Civil Code in the current legal order. Mizan Publications, Twentieth Edition.

Mohebbi, M. (2005). Resolving International Bank Guarantee Letters. Legal Researches Journal, (7), Fourth Edition, Spring \& Summer.

Pepre.f.e.1977 law and practice relation rivised third edition london.

Shahbazi, M. H. (2006). the principles of necessity and permission in the legal acts, First Edition.

Skini, R. (2003). commercial laws (Bill of Exchange, Promissory Note, bills, documents on order of bearer and Bank check). Tehran, SAMT, Eighth Edition.

www.ariatender.com/beta/tarife-zemanatebanki.php

\section{Copyrights}

Copyright for this article is retained by the author(s), with first publication rights granted to the journal.

This is an open-access article distributed under the terms and conditions of the Creative Commons Attribution license (http://creativecommons.org/licenses/by/3.0/). 